\title{
MOTIVASI BERPRESTASI DALAM KAITANNYA DENGAN KINERJA GURU
}

\author{
Doddy Hendro Wibowo \\ doddy.hendro@gmail.com; doddy.hendro@staff.uksw.edu \\ Fakultas Psikologi - Universitas Kristen Satya Wacana Salatiga
}

\begin{abstract}
ABSTRAK
Pendidik merupakan tenaga profesional yang bertugas merencana-kan dan melaksanakan proses pembelajaran, menilai hasil pembelajaran, melakukan pembimbingan dan pelatihan, serta melakukan penelitian dan pengabdian kepada masyarakat, terutama bagi pendidik di perguruan tinggi. Pendidik yang mengajar pada satuan pendidikan dasar dan menengah disebut guru. Kinerja yang maksimal dari seorang guru bertujuan untuk dapat mencapai visi dan misi dunia pendidikan. Tujuan Penelitian ini adalah untuk mengetahui adanya hubungan positif yang signifikan antara motivasi berprestasi dengan kinerja guru di jenjang SMA. Sampel yang digunakan dalam penelitian ini adalah guru di SMA Kristen I dan SMA Kristen II Salatiga sejumlah 46 guru. Hasil uji korelasi yang dilakukan dengan Spearman-Rank, diperoleh nilai koefisien korelasi $\mathrm{r}=-0,092$, dengan probabilitas $0,544(\mathrm{p}>0,05)$. Nilai probabilitas yang diperoleh tersebut lebih besar dari 0,05 , sehingga Ho diterima dan H1 ditolak. Dengan demikian dapat diambil kesimpulan bahwa tidak ada hubungan yang signifikan antara motivasi berprestasi dengan kinerja guru.
\end{abstract}

Kata kunci: Motivasi Berpretasi, Kinerja Guru

\section{PENDAHULUAN}

Pendidik merupakan tenaga profesional yang bertugas merencanakan dan melaksanakan proses pembelajaran, menilai hasil pembelajaran, melakukan pembimbingan dan pelatihan, serta melakukan penelitian dan pengabdian kepada masyarakat, terutama bagi pendidik di perguruan tinggi. Pendidik yang mengajar pada satuan pendidikan dasar dan menengah disebut guru (Undang-undang Republik Indonesia No.20 tahun 2003). Guru juga merupakan suatu profesi yang artinya suatu jabatan atau pekerjaan yang memerlukan keahlian khusus. Berperan sebagai guru tidak semata-mata hanya menjalankan profesinya yaitu mendidik, mengajar dan melatih, namun guru juga memiliki peran dalam bidang kemanusiaan yaitu harus dapat menjadikan dirinya sebagai orang tua kedua di sekolah. Sementara itu di dalam masyarakat, guru diharapkan menjadi tempat untuk memperoleh ilmu pengetahuan serta mencerdaskan kehidupan bangsa (Usman, 1989). 
Kinerja yang maksimal dari seorang guru bertujuan untuk dapat mencapai visi dan misi dunia pendidikan. Namun untuk dapat memaksimalkan hal tersebut dipengaruhi oleh berbagai faktor. Menurut Winardi (2001), ada banyak variabel yang mempengaruhi kinerja individual, misalnya upaya (kerja) yang dikerahkan, kemampuan orang atau individu yang bersangkutan, pengalaman kerja sebelumnya dan adanya motivasi. Sedangkan seorang ahli pendidikan yaitu Terence (dalam Uno, 2001) memandang bahwa kinerja merupakan hasil interaksi atau berfungsinya unsur-unsur motivasi (m), kemampuan (k), dan persepsi (p) pada diri seseorang. Pandangan yang hampir senada dengan ini adalah McDaniel (dalam Uno, 2001) yang mengemukakan bahwa kinerja adalah interaksi antara kemampuan seseorang dengan motivasinya. Moorhead dan Griffin (1998), mengungkapkan bahwa kinerja merupakan hubungan antara motivasi, kemampuan dan lingkungan. Namun di antara faktor tersebut, yang paling penting adalah motivasi, karena motivasi berkaitan dengan pribadi seseorang.

Seseorang yang sangat termotivasi, adalah orang yang melaksanakan upaya substansial, guna menunjang tujuan-tujuan produksi kesatuan kerjanya dan organisasi di mana ia bekerja, sedangkan seseorang yang tidak termotivasi, hanya memberikan upaya minimum dalam hal bekerja (Winardi, 2001). Glickman (dalam Bafadal, 2003) menegaskan bahwa seseorang akan bekerja secara profesional bilamana orang tersebut memiliki kemampuan (ability) dan motivasi (motivation). Maksudnya adalah seseorang akan bekerja secara profesional bilamana seseorang memiliki kemampuan kerja yang tinggi dan motivasi untuk mengerjakan dengan sebaik-baiknya. Sebaliknya, seseorang tidak akan bekerja secara profesional bilamana hanya memenuhi salah satu persyaratan di atas. Jadi betapa pun tingginya kemampuan seseorang ia tidak akan bekerja secara profesional apabila tidak memiliki motivasi kerja yang tinggi. Dengan kata lain, aspek motivasi merupakan komponen paling penting dan berpengaruh dalam kinerja seseorang. Memang ada beberapa hal yang menyebabkan meningkatnya kinerja guru, namun dalam penelitian ini penulis mencoba mengkaji masalah motivasi berprestasi guru.

Suatu penelitian yang mengkaji hubungan antara motivasi kerja dengan kinerja guru dilakukan oleh Sugiyono dan Kuntoro (2004) di SDN Kecamatan Bangkalan Kabupaten Bangkalan Madura. Dalam penelitian ini dikaji tentang pengaruh pembinaan kepala sekolah, motivasi kerja, dan pengalaman diklat terhadap kinerja guru dalam pembelajaran Bahasa Madura. Dari hasil penelitian ini diperoleh hasil bahwa motivasi kerja guru juga berpengaruh positif signifikan terhadap kinerja guru. Jadi dengan perkataan lain konsep motivasi merupakan suatu determinan yang tidak dapat terpisahkan dari suatu kinerja kerja individual. Sedangkan suatu kajian tentang hubungan antara motivasi berprestasi dengan kinerja guru SD telah dilakukan oleh Loekmono dan Pobas (2005) di Kecamatan Polen, Timor Tengah Selatan. Namun dari penelitian tersebut diperoleh hasil bahwa 
tidak ada hubungan yang signifikan antara motivasi berprestasi dengan kinerja guru SD kecamatan Polen Kabupaten Timor Tengah Selatan.

Berdasarkan latar belakang masalah tersebut di atas, maka dirumuskan masalah penelitian, yaitu: Apakah ada hubungan positif yang signifikan antara Motivasi Berprestasi terhadap kinerja Guru di jenjang SMA.

\section{TINJAUAN PUSTAKA}

\section{Kinerja Guru}

Dalam Undang-undang Republik Indonesia No.20 tahun 2003, pendidik yang mengajar pada satuan pendidikan dasar dan menengah disebut guru. Undangundang No.20 tahun 2003 juga mencantumkan bahwa Pendidik merupakan tenaga profesional yang bertugas merencanakan dan melaksanakan proses pembelajaran, menilai hasil pembelajaran, melakukan pembimbingan dan pelatihan, serta melakukan penelitian dan pengabdian kepada masyarakat, terutama bagi pendidik di perguruan tinggi.

Winardi (2001), bahwa ada banyak variabel yang mempengaruhi kinerja individual, misalnya upaya (kerja) yang dikerahkan, kemampuan orang atau individu yang bersangkutan, pengalaman kerja sebelumnya dan adanya motivasi. Sedangkan seorang ahli pendidikan yaitu Terence (dalam Uno, 2001) memandang bahwa kinerja merupakan hasil interaksi atau berfungsinya unsur-unsur motivasi (m), kemampuan (k), dan persepsi (p) pada diri seseorang. Steer dan Parter (dalam Loekmono, 2004) menyatakan bahwa kinerja merupakan gabungan dari 3 faktor, yaitu 1) kemampuan, perangai dan minat seorang pekerja; 2) kejelasan dan penerimaan atas peran seorang pekerja; 3) tingkat motivasi pekerja. Moorhead dan Griffin (1998), mengungkapkan bahwa kinerja merupakan hubungan antara dengan motivasi, kemampuan dan lingkungan. Namun di antara faktor tersebut, yang paling penting adalah motivasi, karena motivasi berkaitan dengan pribadi seseorang. Untuk menentukan suatu kinerja guru, diperlukan beberapa aspek untuk mengukurnya. Sugiyono dan Kuntoro (2004), mengukur kinerja guru menggunakan beberapa indikator yaitu: mengelola program pembelajaran, mengelola interaksi pembelajaran, penguasaan materi pembelajaran, pengelolaan penilaian, dan pelaksanaan kegiatan administrasi pembelajaran.

\section{Motivasi Berprestasi}

Teori motivasi berprestasi muncul dari David C. McClelland (dalam Usman, 2006) yang mengungkapkan bahwa manusia memiliki tiga kebutuhan pokok, yaitu: a). kebutuhan akan prestasi (achievement); b) kebutuhan akan kekuasaan (power); dan 3) kebutuhan akan persahabatan (affilition). Motivasi berprestasi menurut Usman (2006) adalah dorongan dari dalam diri untuk mengatasi 
segala tantangan dan hambatan dalam upaya mencapai tujuan. Kusuma (2004), menjelaskan bahwa motivasi berprestasi adalah dorongan seseorang untuk mengerjakan tugas dengan sebaik-baiknya karena kebutuhan yang didasarkan pada kerangka acuan keberhasilan, yang digambarkan melalui dua indikator yaitu internal dan eksternal. Kristyani (dalam Kusuma, 2004), juga memberikan definisi mengenai motivasi berprestasi, yaitu keinginan dasar untuk mencapai dan menyelesaikan pekerjaan seefektif mungkin. Dari beberapa pendapat ahli di atas, penulis mengambil kesimpulan yaitu motivasi berprestasi merupakan suatu dorongan yang bersumber dari dalam dan luar diri seseorang untuk mengungguli, berprestasi, menyelesaikan tugas sebaik-baiknya, dan seefektif mungkin hingga mencapai suatu tujuan yang telah ditentukan.

Tim Achievement Motivation Training (AMT) Massachuset, (dalam Usman, 2006), mengungkapkan orang yang motif berprestasinya tinggi memiliki indikator: Bertanggung jawab atas segala perbuatannya, mengaitkan diri pada karier atau hidup masa depan, tidak menyalahkan orang lain dalam kegagalannya; Berusaha mencari umpan balik atas segala perbuatannya, selalu mendengarkan pendapat orang lain sebagai masukan atas dirinya; Berani mengambil resiko dengan penuh perhitungan (menantang dan terwujud) melebihi orang lain, lebih unggul, ingin menciptakan yang terbaik; Berusaha melakukan sesuatu secara inovatif dan kreatif, banyak gagasan dan mampu mewujudkan gagasannnya dengan baik. Ingin bebas berkarya, kurang menyenangi sistem yang membatasi geraknya ke arah yang lebih positif. Kekuatan datang dari tindakan sendiri bukan dari orang lain; Merasa dikejar-kejar waktu, pandai mengatur waktunya, yang dapat dikerjakan sekarang jangan ditunda hari esok dan bekerja keras dan bangga atas hasil yang telah dicapai.

\section{Hubungan antara Motivasi Berprestasi terhadap Kinerja Guru}

Motivasi dan motif merupakan dua hal yang berlainan. Usman (2006) mengungkapkan bahwa motif adalah kebutuhan (need), keinginan (wish) dan dorongan (desire). Sedangkan untuk motivasi, McDonald (dalam Hamalik, 2003), mengungkapkan bahwa motivasi merupakan suatu perubahan energi dalam diri (pribadi) seseorang yang ditandai dengan timbulnya perasaan dan reaksi untuk mencapai suatu tujuan. Menurut Robbins (2001), motivasi memiliki pengertian bahwa satu proses yang menghasilkan suatu intensitas, arah, dan ketekunan individual dalam usaha untuk mencapai suatu tujuan. Jadi dari kedua pengertian tersebut dapat diambil kesimpulan bahwa motivasi merupakan suatu proses untuk mencapai tujuan yang disebabkan adanya motif.

Tujuan seseorang dapat tercapai dengan cara atau melalui pemenuhan yang salah satu perwujudannya adalah dengan bekerja. Dengan bekerja secara baik maka kebutuhan dapat terpenuhi. Kusuma (2004) mengungkapkan bahwa jika motivasi seseorang untuk mencapai sesuatu tinggi maka akan semakin tinggi pula 
usaha yang dilakukan untuk mencapai tujuan tersebut. Semakin tinggi taraf kebutuhan untuk berprestasi yang dimiliki seseorang akan menyebabkan motivasinya yang semakin meningkat pula dan kebutuhan berprestasi akan terpenuhi melalui kinerja yang baik sehingga kebutuhan berprestasi dapat terpenuhi. Sedangkan Winardi (2001) mengungkapkan bahwa, seseorang yang sangat termotivasi, yaitu orang yang melaksanakan upaya substansial, guna menunjang tujuan-tujuan produksi kesatuan kerjanya dan organisasi di mana ia bekerja, seseorang yang tidak termotivasi, hanya memberikan upaya minimum dalam hal bekerja. Glickman (dalam Bafadal, 2003) menegaskan bahwa seseorang akan bekerja secara profesional bilamana orang tersebut memiliki kemampuan (ability) dan motivasi (motivation). Maksudnya adalah seseorang akan bekerja secara profesional bilamana seseorang memiliki kemampuan kerja yang tinggi dan motivasi untuk mengerjakan dengan sebaik-baiknya. Sebaliknya, seseorang tidak akan bekerja secara profesional bilamana hanya memenuhi salah satu persyaratan di atas. Jadi betapa pun tingginya kemampuan seseorang ia tidak akan bekerja secara profesional apabila tidak memiliki motivasi kerja yang tinggi.

Munculnya motivasi berprestasi disebabkan adanya kebutuhan berprestasi dalam diri seseorang. Adanya motivasi berprestasi yang tinggi dari seorang guru, akan terlihat dari usaha guru dalam mengemban tugas-tugas yang diberikan kepadanya. Guru yang memiliki motivasi berprestasi tinggi disertai dengan kemampuan yang dimiliki akan memberikan kinerja yang profesional untuk mencapai tujuan yang telah ditentukan. Dengan kata lain, adanya motivasi berprestasi yang tinggi di dalam diri seseorang, di dalamnya ada kinerja yang tinggi pula (Loekmono dan Pobas, 2005).

Hipotesis penelitian yang digunakan dalam penelitian ini adalah: "Ada hubungan positif yang signifikan antara motivasi berprestasi dengan kinerja guru di jenjang SMA yang artinya semakin tinggi motivasi berprestasi maka akan semakin tinggi pula kinerja guru."

\section{METODE PENELITIAN}

Populasi adalah wilayah generalisasi yang terdiri atas; obyek/ subyek yang mempunyai kuantitas dan karakteristik tertentu yang ditetapkan oleh peneliti untuk dipelajari dan kemudian diambil kesimpulannya (Sugiyono, 2005). Populasi penelitian meliputi semua guru di jenjang SMA baik guru tetap maupun guru tidak tetap yang berada di kota Salatiga. Sampel yang digunakan dalam penelitian ini adalah guru di SMA Kristen I dan SMA Kristen II Salatiga. Adapun alasan dipilihnya pemilihan lokasi penelitian di kedua SMA tersebut adalah: Adanya evaluasi terhadap kinerja guru yang dilakukan secara berkala oleh pihak kepala 
sekolah; Jumlah Guru yang memenuhi kriteria sebagai populasi dalam suatu penelitian dan Ketersediaan pihak sekolah untuk menjadi sampel penelitian.

Dalam penelitian ini, untuk alat pengumpulan data digunakan angket. Angket yang digunakan dalam penelitian ini adalah angket yang tertutup. Penulis menggunakan angket sebagai alat pengumpul data dengan alasan bahwa informasi dalam skala luas dapat diperoleh dalam waktu singkat, dapat disebarkan untuk responden yang berjumlah besar dan penggunaan waktu yang lebih fleksibel. Angket atau kuesioner digunakan untuk mengumpulkan data yang termasuk variabel motivasi berprestasi. Sedangkan untuk variabel kinerja guru, data dikumpulkan dengan menggunakan angket penilaian kinerja yang disusun oleh penulis. Pengambilan data akan dilakukan oleh pihak kepala selaku pimpinan.

Metode analisis data merupakan cara untuk mengolah, menganalisis data yang telah terkumpul, dan mengkaji kebenarannya, sehingga diperoleh suatu kesimpulan. Untuk menjawab pertanyaan dalam penelitian ini, maka data yang diperoleh akan dianalisis menggunakan teknik korelasi Pearson product moment. Namun apabila distribusi data tidak normal, maka akan digunakan uji korelasi pada statistik non parametrik dengan teknik korelasi Rank-Spearman dengan menggunakan bantuan komputer program Stastistical Product and Service Solution (SPSS) versi 11 (Santosa, 2004).

\section{HASIL DAN PEMBAHASAN}

Populasi dalam penelitian ini adalah para Guru di jenjang SMA kota Salatiga. Sedangkan sampel yang digunakan dalam penelitian ini adalah keseluruhan dari Guru di SMA Kristen I dan SMA Kristen II dengan teknik pengambilan sampel yaitu sampel aksidental. Pendeskripsian tentang kedua kelompok Subjek penelitian ini dapat dilihat pada tabel 1. Berdasarkan hasil perhitungan normalitas, diketahui bahwa data pada variabel kinerja guru berdistribusi tidak normal, maka uji korelasi yang digunakan adalah SpearmanRank, dengan $\mathrm{N}=46$ maka diperoleh nilai koefisien korelasi $\mathrm{r}=-0,092$, dengan probabilitas $0,544(\mathrm{p}>0,05)$. Nilai probabilitas yang diperoleh tersebut lebih besar dari 0,05, sehingga Ho diterima dan H1 ditolak. Dengan kata lain tidak ada hubungan yang signifikan antara motivasi berprestasi dengan kinerja guru di Jenjang SMA.

Melalui hasil perhitungan korelasi Spearman-Rank, diperoleh nilai r = 0,092 ( $\mathrm{p}>0,05$ ) yang berarti bahwa tidak ada hubungan yang signifikan antara motivasi berprestasi dengan kinerja guru di Jenjang SMA. Hasil ini sesuai dengan penelitian yang dilakukan oleh Loekmono dan Pobas (2005) yang menyatakan bahwa tidak ada hubungan yang signifikan antara motivasi berprestasi dengan kinerja guru. Mungkin ada kelemahan yang diduga dapat menjadikan temuan dalam 
penelitian ini tidak menunjukkan adanya hubungan yang signifikan antara motivasi berprestasi dengan kinerja guru yaitu munculnya penyimpangan dalam penilaian kinerja.

\section{Tabel 1. Deskripsi Subjek Penelitian}

\begin{tabular}{|c|c|c|c|c|c|}
\hline & \multicolumn{2}{|c|}{ SMA Kristen I } & \multicolumn{2}{|c|}{ SMA Kristen II } \\
\hline & & $\begin{array}{l}\text { Jumlah } \\
\text { Subjek }\end{array}$ & $\begin{array}{c}\text { Prosen- } \\
\text { tase }\end{array}$ & $\begin{array}{l}\text { Jumlah } \\
\text { Subjek }\end{array}$ & $\begin{array}{c}\text { Prosen- } \\
\text { tase }\end{array}$ \\
\hline \multirow{2}{*}{ Jenis kelamin } & Laki-laki & 22 & $56,41 \%$ & 9 & $47,37 \%$ \\
\hline & Perempuan & 17 & $43,59 \%$ & 10 & $52,63 \%$ \\
\hline \multirow{2}{*}{$\begin{array}{c}\text { Tingkat } \\
\text { pendidikan }\end{array}$} & S-1 & 38 & $97,44 \%$ & 19 & $100 \%$ \\
\hline & Sarjana Muda & 1 & $2,56 \%$ & - & - \\
\hline \multirow{5}{*}{$\begin{array}{c}\text { Status } \\
\text { kepegawaian }\end{array}$} & Guru tetap & 24 & $61,54 \%$ & 6 & $31,58 \%$ \\
\hline & Guru bantu & 3 & $7,69 \%$ & 7 & $36,84 \%$ \\
\hline & Guru kontrak & 5 & $12,82 \%$ & 3 & $15,79 \%$ \\
\hline & $\begin{array}{l}\text { Guru Tidak } \\
\text { Tetap }\end{array}$ & 7 & $17,95 \%$ & 3 & $15,79 \%$ \\
\hline & TOTAL & 39 & $100 \%$ & 19 & $100 \%$ \\
\hline
\end{tabular}

Soeprihanto (dalam Maruli, 2005) mengungkapkan bahwa ada 3 tipe penyimpangan yakni kelonggaran/ kekerasan, kecenderungan pusat dan penilaian dengan kesan sesaat. Adanya tipe penyimpangan kecenderungan pusat muncul dalam penelitian ini. Apabila dilihat dari skor yang diberikan oleh Kepala Sekolah dalam kuesioner kinerja guru, maka ada kecenderungan bahwa nilai yang diberikan pada angket berada pada/ memusat pada kategori baik. Hal ini mungkin disebabkan selalu adanya kontrol dari pihak kepala sekolah untuk mengatur kinerja para guru sebagai bawahannya.

\section{Tabel 2. Hasil Pengukuran Kinerja Guru}

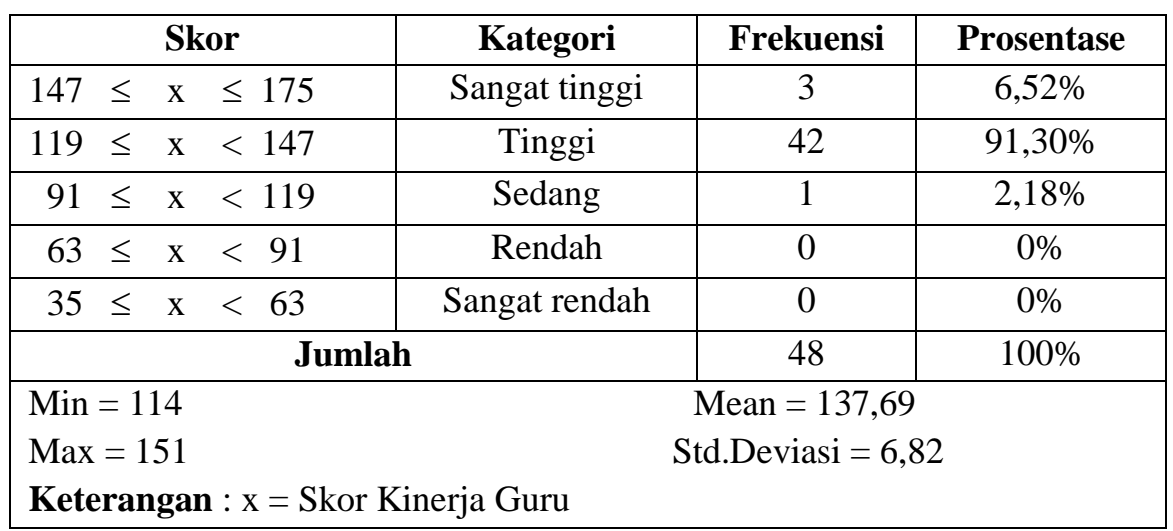


Kinerja dari para guru memang benar-benar dibawah kontrol kepala sekolah. Adanya kontrol tersebut menyebabkan kinerja guru menjadi baik, walaupun seseorang memiliki motivasi yang rendah. Jadi dalam hal ini, lingkungan berperan penting dalam menentukan kinerja seseorang. Namun juga tidak menutup kemungkinan di dalam penilaian yang dilakukan oleh kepala sekolah muncul bias bahwa ada beberapa indikator dinilai, tanpa ada pengamatan yang menyeluruh pada setiap aspek penilaian. Tabel 2 menyajikan data hasil pengukuran kinerja guru.

Namun, lepas dari kelemahan dalam penelitian ini, penulis mengkaji bahwa ada banyak faktor yang mempengaruhi kinerja seseorang. Sonnentag (dalam Rezeki, 2006) yang berpendapat bahwa terdapat berbagai faktor yang mempengaruhi kinerja yaitu perbedaan individual mencakup kemampuan kognitif, kepribadian dan pengalaman kerja, lingkungan atau situasional mencakup karakteristik kerja dan peranan stres serta peraturan kerja mencakup faktor proses perilaku, umpan balik, dan desain organisasi. Jadi selain motivasi, masih ada faktorfaktor lain yang mempengaruhi kinerja seseorang. Moorhead dan Griffin (1998), mengungkapkan bahwa kinerja merupakan hubungan antara motivasi, kemampuan dan lingkungan. Adanya motivasi yang tinggi dari seseorang belum tentu akan menghasilkan kinerja yang baik tanpa didukung oleh faktor kemampuan yang baik pula dan lingkungan yang baik, dalam hal ini adalah sarana dan prasarana yang baik. Mittchel dan Larson (dalam Pasimanjeku, 2003) juga berpendapat bahwa motivasi kerja tidak menjamin kinerja seseorang. Pendapat ini juga didukung Handoko (dalam Pasimanjeku, 2003) bahwa motivasi bukan satu-satunya faktor yang mempengaruhi tingkat kinerja seseorang.

Apabila dilihat dari hasil penelitian maka dapat diketahui bahwa kinerja guru di jenjang SMA berada dalam kategori tinggi. Namun adanya kinerja yang tinggi tersebut tidak lepas dari peran kepala sekolah yang selalu memberikan supervisi dan mengontrol kinerja guru-guru sebagai bawahannya. Adanya iklim kerja yang kondusif, dalam hal ini adalah iklim kerja yang disiplin, perumusan tata tertib kerja secara bersama, kesadaran untuk mentaati tata tertib yang ada dan selalu adanya kontrol dan teladan dari kepala sekolah menjadikan kinerja guru menjadi tinggi. Sebagai contoh, dalam perumusan kurikulum, peraturan, dan anggaran biaya pendidikan dirumuskan secara bersama-sama dan atas kesepakatan bersama. Di dalam keseharian, pihak kepala sekolah juga memberikan teladan bagi para guru untuk bertindak disiplin. Selain itu, pihak kepala sekolah juga selalu mengontrol nilai yang diberikan guru pada murid. Jadi dalam hal ini, pihak kepala sekolah memiliki peran penting dalam mengatur kinerja para guru.

Berdasarkan dari penjelasan di atas, dapat dilihat faktor-faktor yang mempengaruhi hasil penelitian ini. Faktor iklim kerja dan lingkungan tempat kerja memegang peranan yang besar dalam menentukan kinerja seorang guru. 


\section{SIMPULAN DAN SARAN}

Berdasarkan hasil penelitian yang diperoleh, maka dapat ditarik kesimpulan sebagai bahwa tidak ada hubungan yang signifikan antara motivasi berprestasi dengan kinerja guru di jenjang SMA.

Bagi penelitian selanjutnya yang ingin melakukan dan mengembangkan penelitian ini, diharapkan agar: Melakukan wawancara awal atau identifikasi mengenai latar belakang tempat penelitian secara menyeluruh, sehingga dapat diciptakan alat ukur yang lebih sesuai dengan keadaan di tempat penelitian; Memperhatikan waktu yang tepat dalam pembagian angket di sekolah, sehingga seluruh guru yang mengajar mendapatkan angket; Mencoba metode pengumpulan data yang lain, misalnya observasi langsung khususnya untuk melihat variabel kinerja guru; Mencoba mengembangkan variabel penelitian yang lain yang dipadukan dengan motivasi berprestasi misalnya iklim organisasi, lingkungan kerja, kedisiplinan, pengalaman mengajar, latar belakang pendidikan atau gaya kepemimpinan kepala sekolah.

\section{DAFTAR PUSTAKA}

Bafadal, I. 2003. Peningkatan Profesionalisme Guru Sekolah Dasar. Jakarta: Bumi Aksara.

Hamalik, O. 2003. Proses Belajar Mengajar. Jakarta: Bumi Aksara.

Kusuma, I.H. 2004. Study Korelasional Antara Kecerdasan Adversity dan Motivasi Berprestasi dengan Kinerja Kepala Sekolah di Lingkungan Yayasan BPK Penabur Jakarta. Tersedia di: http:// www. depdiknas. go. id/ kinerja. Diakses tanggal 2 Februari 2007.

Loekmono, \& Pobas. 2005. Hubungan antara Motivasi Berprestasi dengan Kinerja Guru SD Kecamatan Polen, Timor Tengah Selatan. Satya Widya Jurnal Penelitian Pengembangan Kependidikan, 18(2), 152 - 157.

Maruli, N. 2005. Hubungan Antara Penilaian Kinerja Keperawatan dengan Kualitas Pelayanan Keperawatan. Skripsi (tidak diterbitkan). Salatiga: Fakultas Psikologi Universitas Kristen Satya Wacana.

Moorhead, G., \& Griffin, R. W. 1998. Organizational Behavior. Boston, New York: Houghton Mifflin Company.

Pasimanjeku, A. 2003. Pengaruh Tingkat Pendidikan dan Motivasi Kerja Terhadap Kinerja Mengajar Guru-guru SLTP Negeri 3 Getasan Kabupaten Semarang. Tesis (tidak dipublikasikan). Salatiga: PPS Magister Manajemen Pendidikan. 
Motivasi Berprestasi dalam Kaitannya dengan Kinerja Guru (Doddy Hendro Wibowo)

Rezeki, S. 2006. Hubungan Antara Kepuasan Kerja dengan Kinerja pada Pegawai Negeri Sipil. Skripsi (tidak diterbitkan). Salatiga: Fakultas Psikologi Universitas Kristen Satya Wacana.

Robbins, P. S. 2003. Perilaku Organisasi. Jakarta: PT Indeks kelompok Gramedia.

Santosa, S. 2004. SPSS Versi 10 Mengolah Data Statistik Secara Profesional. Jakarta: Elex Media Komputindo.

Sugiyono. 2005. Metode Penelitian Bisnis. Bandung: Alfabeta.

Sugiyono \& Kuntoro. 2004. Pengaruh Pembinaan Kepala sekolah, Motivasi Kerja, dan Pengalaman Diklat terhadap Kinerja Guru dalam Pembelajaran Bahasa Madura di SDN Kecamatan Bangkalan Kabupaten Bangkalan Madura. Jurnal Penelitian dan Evaluasi, 7. 157 -172.

Undang-Undang Republik Indonesia No. 20 tahun 2003. Sistem Pendidikan Nasional. Bandung :Citra umbara.

Uno, H. dkk. 2001. Pengembangan Instrumen untuk Penelitian. Jakarta : Delima Press.

Usman, H. (2006). Manajemen Teori, Praktik, dan Riset Pendidikan. Jakarta: Bumi Aksara.

Usman, M.U. 1989. Menjadi Guru Profesional. Bandung: Remaja Rosdakarya.

Winardi, J. 2001. Motivasi dan Pemotivasian dalam Manajemen. Jakarta: Rajawali 